\title{
Digital Masorah: Toward an Index of Orthographic and Morphological Variation at the Lexical Level
}

\section{Johan de Joode}

https://orcid.org/0000-0001-7209-880X

KU Leuven, Belgium

johan.dejoode@kuleuven.be

\section{Abstract}

This article proposes a computational method to extract orthographic and morphological variation within the boundaries of individual documents that are part of the Hebrew Bible or the Dead Sea Scrolls. In particular, it presents "profiles" of document-internal variation at the lexical level, e.g., at the level of individual words. This study a) describes the methods used to create an index of variation that can be navigated and explored in order to find meaningful patterns, and b) explores the new avenues for research such an index opens up. Whereas earlier contributions have focused on the underlying rules that affect linguistic variation, the aim of the present contribution is to create a representative sample of that variation. This sample is not at the level of individual phonemes or morphemes, but at the lexical level as there are clear indications that lexical selection played a significant role in ancient linguistic practices.

Keywords: spelling index; digital Masorah; orthography; morphology; variation; quantitative linguistics

\section{Introduction}

This contribution introduces a computational method that extracts orthographic and morphological variation within individual documents that are part of the Hebrew Bible and the Dead Sea Scrolls. In particular, it describes a powerful, novel way of automatically extracting linguistic variation based on existing digital databases of linguistic information. This procedure results in a representative sample of linguistic

\section{UNISA}


variation for the entire corpus on the one hand, as well as a "profile" of the documentinternal variation linked with hypertext to concordances, on the other hand. ${ }^{1}$

In the concluding pages of his 1989 monograph, James Barr suggests,

For each biblical book a short profile of its spelling tendencies should be prepared [...] Such a profile should not seek to present every detail but rather should give an adequate general impression of the contours of spelling within the book. (Barr 1989, 212)

In the appendix to his work, Barr provides an example for the Psalms, hoping that exegetical commentaries and grammars would provide similar orthographic profiles for other biblical books. His suggestion is rarely followed possibly because the available linguistic evidence is complex and hard to navigate, and because there is no consensus on the underlying principles of linguistic change as it is reflected in the Masoretic traditions. The present contribution aims to provide an initial step towards the creation of profiles of orthographic and morphological variation for biblical books and the Dead Sea Scrolls. ${ }^{2}$

\section{Background}

There is a long-standing tradition that investigates the data pertaining to disjointed, haphazard spelling in an attempt to recognise patterns. In their foundational study Spelling in the Hebrew Bible, Andersen and Forbes (1986) extract patterns of the use of vowel letters as related to stress, spelling type, spelling choice, and text portion. Their efforts constitute a large-scale, statistical analysis of the factors that influence spelling choice. ${ }^{3}$ They discover that when quantified and tested for statistical significance, their pre-defined spelling types correlate with a chronological development towards more vowel letters. Hence, the distribution of vowel letters serves as a ground for estimating the relative age of the documents at hand. Andersen and Forbes's approach has been criticised, mostly because some of the extant epigraphical material and the oldest parts

1 This contribution is the first of a two-part computational study of orthographic variability. The present study introduces the creation of the data. The dataset that accompanies this article can be accessed at https://doi.org/10.5281/zenodo.3824571 or https://github.com/jdejoode/orthomorphindex-JSEM. The second study quantifies and compares the orthographic homogeneity of the texts based on the data. The research for this article was conducted as part of the project A Corpus Linguistic Approach of Classical Hebrew: A Pilot Project (3H160213, KU Leuven, with as principal investigators Eibert Tigchelaar and Pierre Van Hecke).

2 Orthographic variation has been studied more extensively in the literature than morphological variation. The present study focuses both on orthographic and morphological variation since the technical means I propose to extract variation do not a priori distinguish between the two types of variation.

3 Despite the criticism they have received for being too mathematical, they present the first corpus-wide study of spelling variation using statistical modelling. Cf. also Freedman, Forbes and Andersen (1992). 
of the Hebrew Bible contain vowel letters. ${ }^{4}$ To date, however, neither their methods nor their findings have been invalidated. Although their book contains numerous statistical analyses that indicate which spelling types are outliers in specific portions of the Hebrew Bible (Andersen and Forbes 1986, 246-84), the results are organised per type of variation rather than per text portion. This mode of presentation conflicts with the profile-based approach Barr argues for. The authors' final sentence is that "much work remains to be done." The current index takes up the gauntlet: it complements the computational approach pioneered by Andersen and Forbes as it aims to provide a sample of the linguistic variation per book or per scroll. ${ }^{5}$

The study of spelling variation has focused on identifying the factors that influence or trigger the extant variation. ${ }^{6}$ Many hypotheses have been investigated including the dating of the composition (cf. supra), the frequency of the word that varies, the proximity of the same spelling, the length of the word, its morphological class, its level of stress, the adjacent graphemes, the numerical values of words, the length of the lines, the avoidance or reduction of semantic or morphological ambiguity, and the presence of an affix. ${ }^{7}$ Barr $(1989,194)$ claims that variation is a stylistic means: it allows copyists a certain liberty to express themselves without altering the text too much. ${ }^{8}$ Possible rules underlying the practice include general patterns such as "avoid sequences of two identical letters", or "avoid using multiple matres lectionis in a single word" (Ariel 2013, 942). These insights are often paired with observations about specific spelling practices in an attempt to link them to scribal preferences or even dialect (Ariel 2013, 945-47; Freedman 1969, 44-46; Tov 2004).

The stakes of understanding orthographic and morphological variation are high. Individual orthographic and morphological variants rarely affect the meaning of a text (Barr 1986, 8), although they do sometimes provide valuable pointers. Patterns of orthographic and morphological variation, however, do regularly function in the literature when they are used to classify texts based on their shared provenance (Tov 2004), for instance. In view of the diachronic changes in spelling practice, insight into

4 On the extant material, cf. Zevit (1980) and Kofoed (2005). Andersen and Forbes $(1986,319)$ are explicit about the fact that "there is no trace in the Hebrew Bible of texts using purely consonantal (Phoenician) spelling."

5 The data presented in this contribution do not replace Andersen and Forbes's work, but can complement their findings.

6 The search for patterns in spelling variation also took place in other corpora such as, for instance, the epigraphic evidence, as well as the Dead Sea Scrolls, or more specifically, Qumran Hebrew (Cross and Freedman 1952; Weinberg 1985). Likewise, several studies focus on peculiarities found within individual documents such as the book of Job (Freedman 1969; Seow 2011).

7 For many of these features, cf. Andersen and Forbes (1986, 2-3, 104-05). For the affix effect and an extended discussion of ambiguity, the effect of the first occurrence of a lexeme, and of line length, cf. Barr (1989, 25ff., 188ff.). Several of these possible causes have been identified and discussed by Rahlfs (1916).

8 Also cf. Rahlfs (1916) and Andersen and Forbes (1986, 317). 
a document's orthography can be used to understand when a text was composed (Andersen and Forbes 1986; Hornkohl 2014). Likewise, it is claimed that certain sources of the Pentateuch show a similar orthographic profile (Dershowitz et al. 2014). In light of such high stakes, a solid grasp of orthographic and morphological variation within individual documents and across documents is pivotal for a critical understanding of the historical and social background of the texts.

The factors that influence linguistic choice are multifaceted; they include at least four interrelated variables that are next to impossible to isolate. Firstly, it is generally assumed that there is a gradual increase in the use of vowel letters over time. When is the presence of a linguistic variant the result of such a diachronic change? Secondly, the identification of orthographic and morphological variation is dependent on a solid understanding of the phonology of the lexical items that are represented, yet there is uncertainty about certain phonological reconstructions. Moreover, an all too explicit dependency on Masoretic vocalisation might misrepresent phonetic and phonological differences that affect certain spellings. According to Barr $(1989,36)$, for instance, the spellings of מאם are consistent because they were pronounced differently than is generally presumed. Thirdly, there are differences between the manuscript traditions. It is ambivalent whether a spelling choice reflects the preferred spelling of a scribe or the spelling of the Vorlage. The very limited insight into the transmission and composition history of the manuscripts further complicates the matter. Finally, linguistic choice is likely to have been influenced by dialect. The proposed Sitz im Leben of individual texts is often based on the description of dialectal and cross-linguistic influence (for the book of Job, cf. Freedman 1997; Seow 2011). The issue of linguistic choice in the Hebrew Bible and the Dead Sea Scrolls is hence a complex issue, e.g., there is no single variable that explains (let alone predicts) the variation. In light of the multivariate nature of linguistic choice in the corpora at hand, it is worthwhile a) to provide a representative sample of linguistic variation per document in a way that is easy to navigate, and b) to gain insight into the extent of the variation as well as the homogeneity of individual documents (de Joode and Speelman 2020).

\section{Corpus and Terminology}

The three corpora used for this study are the Hebrew Bible, the "biblical" Dead Sea Scrolls, and the "non-biblical" Dead Sea Scrolls. ${ }^{9}$ Only documents that contain 5000 non-edited and non-reconstructed tokens are selected, where a token is either a suffix or an item that has its own morphological parsing..$^{10}$ Of the following modules present in Accordance 11.2.5 the full text and the morphological parsing were exported: the Biblia

9 This terminology is used despite its evident anachronism because it is part of the names of the respective Accordance modules.

10 Only non-edited and non-reconstructed forms are selected in order to avoid measuring variation in reconstructed or edited forms. 
Hebraica Stuttgartensia (henceforth BHS; version 1.7), ${ }^{11}$ Qumran Non-Biblical Manuscripts (henceforth Qumran; version 4.2), and Dead Sea Scrolls Biblical Manuscripts DSSBM (henceforth DSSBM; version 3.2). ${ }^{12}$ The corpora are referred to using Accordance's nomenclature, although that distinction is not of prime importance for our purposes, especially given the fact that in DSSBM only 1QIsa ${ }^{a}$ meets the above criteria. ${ }^{13}$ The system for labelling morphological parsing is, with a few important exceptions that were incoherent in the dataset, identical in these corpora and it follows the morphological tags described in the Accordance documentation. For the preparation of the corpus a series of custom scripts were written in the programming languages Python and R. ${ }^{14}$ The text of BHS is based on Codex Leningradensis. Kethib or Qere tokens are excluded from the analysis based on an alignment of the database with the database from the Eep Talstra Centre for Bible and Computer (henceforth ETCBC). ${ }^{15}$ At times, the exclusion algorithm also removes a few words before or after the Kethib form. The data as exported from Accordance also contains a number of mistakes when compared with dataset provided by Miklal. ${ }^{16}$ In total, approximately 2600 words were excluded from the corpus. BHS is stripped of vowels. This dataset is referred to as the corpus or the corpora if reference is made to the BHS, Qumran, and DSSBM as separate corpora.

The terminology used to study variation at scale includes terms such as variable, variant, and variety. ${ }^{17} \mathrm{~A}$ variable is a unique profile that encapsulates several variants for the same spelling choice, where a variant is an actual spelling variant. For instance, the variable ארצות as feminine plural noun in the absolute state has the variants ארצת. The variety, then, is the language variety in which the variables are measured. In

11 The choice for the digital version of BHS, itself based on manuscript B19a, Codex Leningradensis, is solely motivated by the availability of the data. As more digital copies of different medieval manuscripts become available, this study will have to be replicated. The data that are reproduced and enriched only contains the varying items, without any indication of their actual locations in the documents. Based on these data and their concordances it is not possible to reconstruct the texts themselves. Hence, the author is of the opinion that the use of the data is fair.

12 The Accordance data and software are regularly updated; hence, the results presented in this study only hold for this specific iteration of the software and data. Possibly, some of the issues described below will have been dealt with by the time of publication.

13 This choice is for practical purposes only. It does not reflect a position in the debate about the provenance and Sitz im Leben of the scrolls.

14 Besides the full text in horizontal format also the morphological parsing in vertical format was extracted and the full text and morphological data were aligned as the morphological parsing does not contain data about the lacunae. For that purpose, an alignment script was created in Python. This alignment is not perfect, but it has very low error rates.

15 The latter was not used for the entire analysis as it lacked the Dead Sea Scrolls at the time of the analysis.

16 These export errors in the data from Accordance are often due to the presence of footnotes in the text that are wrongly converted to Hebrew characters. The Miklal data can be consulted at https://www.miklalsoftware.com/transliteration-products/.

17 Dirk Speelman, personal communication. 
traditional dialectometry this can be likened to American English compared with British English. In this case, the language varieties are the documents in which the spelling variants can be found. Whether it is natural to think of documents as language varieties is not what is at stake at this point. For practical reasons one can assume that documents are language varieties without excluding the possibility that multiple documents actually are part of the same variety. A spelling variable can also be termed a profile and the individual occurrence of a specific spelling variant is a spelling instance; the latter is the actual word as it is found in the document.

\section{Method}

There is no scholarly consensus on the definition of a variant and on how to extract orthographic and morphological variants. A number of systematic studies of spelling have collected their data in different ways. Andersen and Forbes (1986) define 65 spelling types mostly at the syllable level which reflect whether a vowel letter could be found in the given syllable. Barr $(1989,44,81)$, however, presents 21 "groups of evidence" including "the plural terminations - im and - ot" and the "the i vowel of hiphil in the triliteral verb." Dershowitz et al. (2014) created a dataset of manually tagged historical and etymological spellings that were disambiguated by an expert. Tov's (2004) description of the orthographic and morphological variation in his theory of Qumran scribal practice starts from 18 features some of which are also full words. His classification of orthographic and morphological features in the scrolls is essentially also binary, where a "default" variant is set apart from an alternative orthography or morphology, although the alternative is not necessarily a single variant spelling. Abegg (2010, 52-58) describes the spelling preferences per document based on 17 actual words. ${ }^{18}$ However, none of these datasets have been made public.

It is possible, however, to compute spelling variation not as the presence or absence of a vowel letter, but as the choice for one out of multiple ways to spell a specific word. To be able to study document-internal variability at the lexical level, one can leverage the existence of datasets which contain both lemmata and morphological parsing. Based on the corpus, an automated index of variation can be created. ${ }^{19}$ This requires the following steps. Firstly, all tokens are grouped by unique lemma and morphology combinations. This is a crucial step in the process. For example, to find all the variants spellings of אלהים we query the morphological and lexical database for all items that have the lemma אלהים and the morphological parsing noun common masculine plural absolute (NCMPA in Accordance). This results in the spelling variants אלהים ,אלוהים and אלוים. This grouping, first by lemma and subsequently by morphological parsing, entails that construct forms, for instance, are distinguished from absolute forms. When

18 Alexander and Vermes $(1998,7)$ use a few keywords and forms to determine whether a text is primarily full or defective.

19 There is a tool to tag spelling variation, but it is not adapted to Hebrew; cf. Baron and Rayson (2008). 
applied to all lemmata and their respective morphological parsings, a rudimentary, yet compelling index of variation is constructed containing the frequencies for all variants on the word level. The result is a series of variables or profiles, viz. unique lemmamorphology combinations, that provides a snapshot of the variability for the occurrence of a specific form of a specific lexeme. For instance, Table 1 contains an example of the variable ל-Negative Particle in Jeremiah. ${ }^{20}$ These lemma-morphology combinations, with the improvements described below, can be computed for any document.

Table 1. Example of the spelling profile for לא-Negative Particle in Jeremiah

\begin{tabular}{lllr}
\hline לאיא & Negative Particle & 475 \\
\hline
\end{tabular}

The second step in the creation of the index of variation is the adaptation of the previously constructed profiles to reflect the peculiarities of Hebrew. Linguistic variation consists of variants with the same lemma and an identical morphological parsing in a similar context, but with a different surface form. The type of index created by the first step fits our definition of variation only partially as the context is not taken into account yet. The effect of construct forms, as observed by Dershowitz et al. (2014), is taken into consideration as it is part of the morphological parsing, but the presence of affixes is not, despite the fact that Barr has shown that they are significant. It is known that "defective spelling is more common when a word has a pronominal suffix or is in the construct state" (Ariel 2013, 942). Barr (1989, 14-15) explains, "affix effect means that plurals have to be taken separately from singulars, forms with pronoun suffixes separately from forms that do not have them; constructs and forms with the article may require to be treated separately." For the purpose of the present study, a number of manipulations were made to adapt the data. The presence of the definite article or a prefix is not taken into account in order to avoid data sparsity. ${ }^{21}$ The most notable change, however, is the separation of morphological codes into cases without a suffix, with a heavy suffix, or with a light suffix. This also involves moving the yôd indicating a plural suffix to the suffix rather than the headword and labelling the function of a suffix as related to its headword (for instance, common noun masculine singular construct state with a light suffix).

The lemma מן was excluded from the index because of the complex patterns related to its different morphological forms and their effect on the suffixes (which affect a great number of the suffixes). If compound proper names are separated with a maqqêf, e.g.,

20 These counts are only for the negative particle when it is not prefixed with an interrogative particle (cf. infra).

21 The only exception to this rule is the negative particle לא of which it can be observed that the prefixed interrogative particle does alter its spelling (Eibert Tigchelaar, personal communication). 
אי־כבוד, the maqqēf and the space separating the two compounds is removed in order to avoid extracting the compounds as separate variants.

The editors of the Dead Sea Scrolls often use slightly different conventions to transcribe the manuscript. Some editors are more eager than others to mark an editorial intervention, an illegible character for instance. Until a new digital scholarly edition of the corpus is created (or finished), these differences are likely to persist. The differences between scholarly editions affect the lack of systematicity in the rendering of final forms or the use of non-final forms in word-final positions in the scrolls. For that purpose, the text was "desofitised", meaning that all cases of final forms were replaced by their nonfinal counterparts. Despite the above changes, the present study wants to minimally alter the data. ${ }^{22}$ Table 2 shows a sample of the profile for Jeremiah.

Table 2. Sample of the variables (and their variants) extracted for Jeremiah

Spelling Variable/Profile

\begin{tabular}{|c|c|c|c|}
\hline לא & Negative particle & לא & 475 \\
\hline & & לוא & 34 \\
\hline לא & Na Negative particle after & 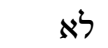 & 2 \\
\hline & & 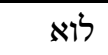 & 14 \\
\hline כּל & $\begin{array}{l}\text { Noun masculine singular in } \\
\text { construct state }\end{array}$ & כול & 2 \\
\hline & & כל & 453 \\
\hline 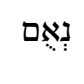 & $\begin{array}{l}\text { Noun masculine singular in } \\
\text { construct state }\end{array}$ & נאומ & 1 \\
\hline & & 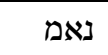 & 175 \\
\hline אמר & Verb qal infinitive construct & 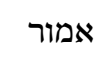 & 2 \\
\hline & & 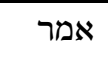 & 114 \\
\hline ישב & $\begin{array}{l}\text { Verb qal participle masculine } \\
\text { plural in absolute state }\end{array}$ & 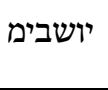 & 2 \\
\hline & & ישבימ & 11 \\
\hline
\end{tabular}

22 Of course, one could make different choices. It is possible, but not necessary, to write an algorithm that merges spelling types together if they are construct and absolute forms which display no difference between the profiles. This type of merging was not performed for reasons explained below. 


\begin{tabular}{|c|c|c|c|}
\hline מוֹסֵרָה & $\begin{array}{l}\text { Noun feminine plural in construct } \\
\text { state with a light suffix }\end{array}$ & מוסרות & 1 \\
\hline & & מוסרת & 1 \\
\hline \multirow[t]{2}{*}{ גָּד גוֹל } & $\begin{array}{l}\text { Adjective feminine singular in } \\
\text { absolute state }\end{array}$ & גדולה & 5 \\
\hline & & גדלה & 1 \\
\hline \multirow[t]{2}{*}{ מות } & $\begin{array}{l}\text { Verb qal imperfect third masculine } \\
\text { plural }\end{array}$ & ימותו & 1 \\
\hline & & ימתו & 5 \\
\hline \multirow[t]{2}{*}{ פקד } & $\begin{array}{l}\text { Verb qal participle masculine } \\
\text { singular in absolute state }\end{array}$ & פוקד & 1 \\
\hline & & פקד & 5 \\
\hline
\end{tabular}

\section{A Matrix of Variation}

The list of these profiles for a given document captures a highly indicative sample of the orthographic and morphological variation attested within that document. It is a sample because the method to select and extract the spelling variation by definition also ignores certain variants, for instance by treating the absolute and construct forms of nouns separately, although they might be identical in form or although this treatment might cause one of the profiles to only contain a single spelling instance (thus not being capable of showing variation). When the profiles for the individual documents are aligned, an overall matrix of variation is created that enables the study of linguistic variation in the entire corpus. Table 3 is an example of a matrix where the rows represent variants grouped per variable, and the columns are language varieties, or in this case simply documents. This table is only a short, curated sample of a table that contains thousands of variants. It purposefully uses documents that are not the focus of this study in order to draw attention to the way in which a variation matrix can be studied. ${ }^{23}$

23 When, in the analyses below, 1QIsa ${ }^{a}$ is split into two separate documents that choice is based on qualitative arguments that assume two scribal hands, or at least two orthographic traditions that can be discerned (Ulrich and Flint 2010, 63-64). 
Table 3. Sample of a variation matrix

\begin{tabular}{|c|c|c|c|c|c|c|c|c|c|c|}
\hline & & 11Q19 & 11Q5 & $1 Q 8$ & $1 Q H^{\mathrm{a}}$ & 1QIsaa ${ }^{a} 1$ & 1QIsa ${ }^{a}{ }_{2}$ & $1 Q M$ & $1 Q S$ & Mur88 \\
\hline \multirow[t]{4}{*}{ AFSA } & זאות & 1 & & & & 3 & & & & \\
\hline & זאת & 1 & & 5 & 2 & & & & & 5 \\
\hline & זואת & 16 & 2 & & & 23 & 13 & & 1 & \\
\hline & זות & & & & 4 & 2 & & & 3 & \\
\hline \multirow[t]{2}{*}{ NCMSA } & בסר & & & & 1 & & & & & \\
\hline & בשר & 3 & 1 & & 20 & 7 & 4 & 4 & 2 & \\
\hline \multirow[t]{3}{*}{ PC } & כי & 71 & 83 & 61 & 94 & 128 & 2 & & 1 & 32 \\
\hline & כיא & 2 & & & 38 & 83 & 112 & 24 & 33 & \\
\hline & כיה & & 1 & & & & & & & \\
\hline \multirow[t]{4}{*}{ NCMSA } & ראוש & 1 & & & & 3 & & 1 & & \\
\hline & ראש & & & & & 1 & & 3 & & 1 \\
\hline & רואש & & 2 & & & 2 & & 2 & & \\
\hline & רוש & & & & & 2 & & & & \\
\hline
\end{tabular}

A matrix of this kind can not only be used to identify linguistic variation within a single document, but also to compare linguistic practice across the varieties under scrutiny. For the purpose of the present contribution it suffices to highlight that such a "variation matrix" quantifies the variation within a document: at a glance, it can be observed that 11Q19 has a preference for the spelling זואת with two exceptions (זאת and whereas Mur88 systematically uses זאת. Whereas some profiles/variables have a clear preferential variant with the occasional exception, other profiles for specific documents are far less outspoken: in the Hodayot, for instance, the particle כיא is used 38 times and כי is used 94 times. Empty cells represent the absence of any occurrences. Not all these differences are matters of vowel letters: they can also include variations in the usage of the sibilants (בשר and בסר and, for example. Again, small divergences in counts are possible, for instance, because of the strategies used to exclude fragmentary words and parts of words and/or because of errors in the data, but the underlying principles of this analysis are illustrated by this matrix. Although a large proportion of profiles are binary, there are many variables which have more internal variation (זאת as adjective feminine singular in absolute state has four variants and the same holds for ראש as common noun 
masculine singular in absolute state). Most importantly, it demonstrates that quantifying spelling choice in terms of visible, recognisable, and atomic spelling variants and not higher abstractions makes it possible to represent information on spelling practice concisely and in a way that is easily understood by exegetes and philologists alike. Based on the index it is possible to evaluate whether documents make different linguistic choices.

Table 3 also illustrates that certain variants can be highly idiosyncratic. The spelling in 11Q5 is very surprising not only because it occurs a single time, but also because it occurs in a single variety under scrutiny in this table. In the case of כיה מיה this possibly a mistake in the morphological parsing, and it is one of the reasons a frequency filter at the level of individual variants will be introduced in due time. ${ }^{24}$ One of the types of information that can be deduced from this matrix is the document frequency, viz. the total number of documents/varieties in which a variant is found. The document frequency differs from the actual frequency (often called absolute frequency) of the occurrence of a variant, which in this case is also one, viz. it occurs a single time. In sample Table 3, the variant ראש has an absolute frequency of one in 1QIsa ${ }_{-}^{a} 1$, but it has a document frequency of three (it is part of $1 \mathrm{QIsa}_{-}^{\mathrm{a}} 1,1 \mathrm{QM}$, and Mur88). Hence, the matrix provides complementary means of understanding spelling variation using straightforward counts. The (absolute) frequencies provide counts for each variant. The document frequencies measure the distribution of a variation within all the documents. The number of rows within a variable show how many different variants a profile contains. The frequency counts provide insight into the spelling choices that a document makes (for instance, 11Q19 prefers כי with 71 occurrences vs. two for as well as the degree in which there is one single variant which dominates the document, or whether there is more internal variability, as, for example, ראוש, ראש ind and (de Joode and Speelman 2020).

Both the index of variation and the individual profile for a document can be extended with the type of frequency information introduced above. Table 4 shows a sample of the profile for 2 Samuel with six additional types of frequency information, e.g., the relative frequency, the absolute frequency in the corpus, the frequency of the variable, the number of variants in the corpus, the document frequency, and the relative document frequency. ${ }^{25}$ 
de Joode

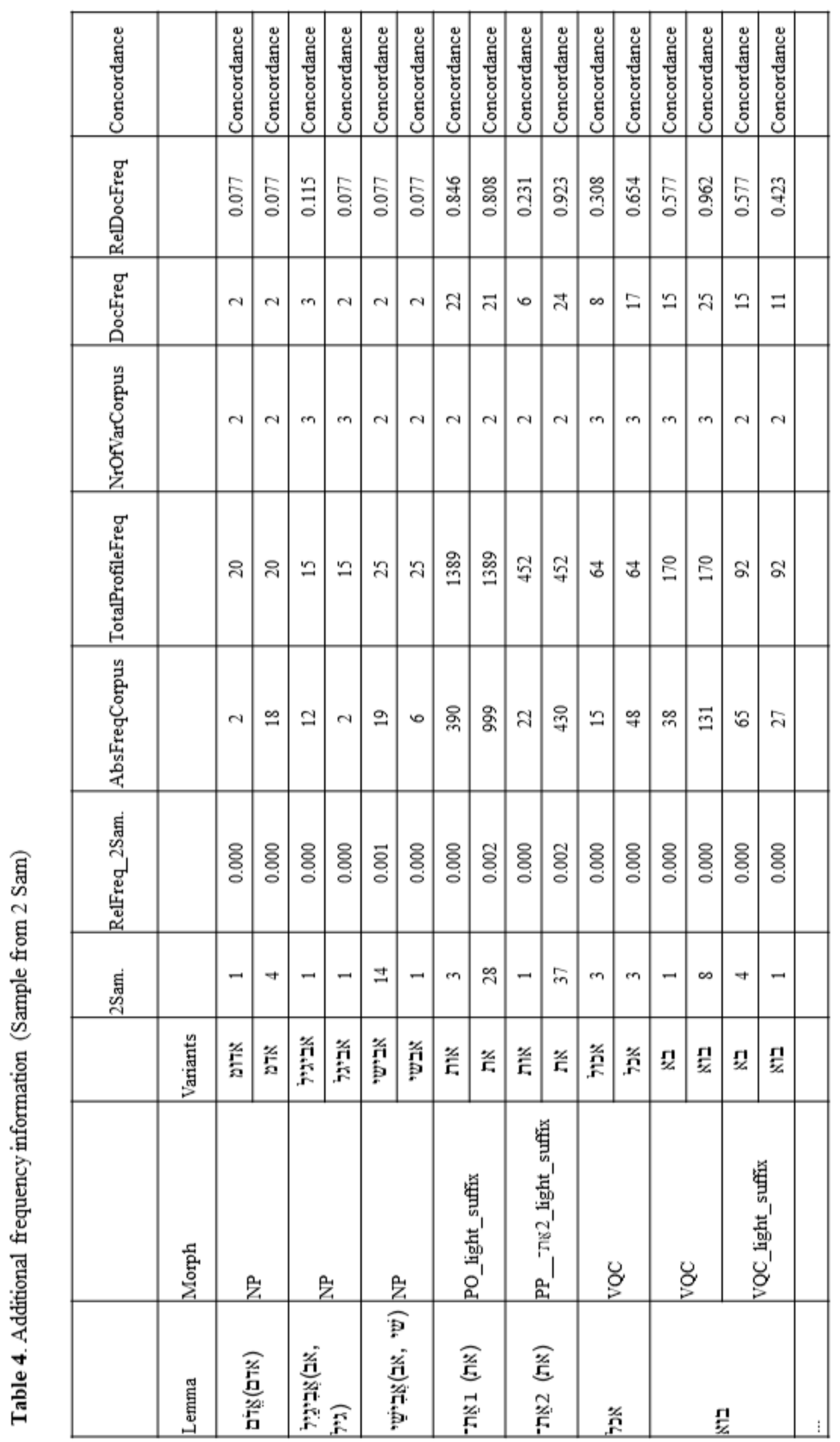


The relative frequency of a variant in a given document indicates the frequency of that variant in proportion to the total number of words in the document. For instance, if a variant has a relative frequency of 0.002 , it occurs twice per 1000 words in the document. ${ }^{26}$ The absolute frequency of the profile in the corpus is the same for all variants: it allows for filtering the profile on high-frequency or low-frequency variables. The number of variants in the corpus indicates how many variants are present in the entire corpus. It is possible that a document only contains two variants, but that other variants are found elsewhere in other documents. The document frequency is the number of documents in which a given variant is found. The relative document frequency is the proportion of documents that contain the variant. The relative document frequency provides insight into how idiosyncratic a variant is (for instance, if it only occurs in two documents, it will have a low relative document frequency such as 0.077 whereas a variant that occurs in 25 documents has a relative document frequency of 0.962 , viz. $96 \%$ of the documents contain the variant). The html files distributed with this contribution provide a hyperlink to a concordance for a variant in the given document. This makes the index easy to navigate in a browser. This is a first step towards Barr's $(1989,210)$ suggestion that "thought should be given to the preparation of a concordance of a type that would be especially suitable for the study of spelling." The results of the method proposed in the preceding section is thus both a general index of all variation across documents as well as an index per document. The general index of all variation also includes items that are fully consistent in a single document.

\section{Advantages of Indexing at the Lexical Level}

The present section, as does the next, highlights a number of advantages and challenges that are inherent to a study of variation at the lexical level. Whereas earlier studies have focused on abstract spelling types which are often at the level of syllables, the focal point of this study is the lexical level, e.g., the level of individual words. There are five reasons why the study of linguistic variation at the lexical level is promising. Firstly, both Andersen and Forbes and Barr have identified a considerable number of highly frequent lexical items of which the spelling is rather consistent. Andersen and Forbes (1986, 126ff.) dedicate a special section to these fixed spellings. Barr $(1989,36)$ highlights the consistency of the spellings of, for instance, נאם, מאד,כהן, and . אלהים. Variability is prominent in the description of linguistic practice in the corpus, but there are also very specific cases which escape the overall heterogeneity. Barr (1989, 36) argues that this consistency is the result of a "lexically selective convention." It is not unthinkable that copyists and authors alike who systematically prefer specific spellings for certain words also extend that tendency to other words in the lexicon, although these choices might be less visible or even less systematic. This would suggest that, albeit in embryonic form, there might be an effect of "lexical selectivity" (Barr 
1989, 36) or "word-level conditioning" (Andersen and Forbes 1986, 271) that influences spelling choice also for non-fixed spellings. ${ }^{27}$ If the spelling choices of copyists/authors are influenced by certain lexically determined categories, the study of linguistic variation at the lexical level is warranted. This does not entail that all linguistic variation can be explained by the influence of lexis, but it is definitely a factor that needs investigation.

Secondly, it is evident that the Masoretes counted and captured small variations within (groups of) documents often at the lexical level. Barr stresses, "a very high proportion of the Masoretic notes concern [spelling]." He continues to claim that "the main technique of the Masora can be simply stated: it registers the minority spelling" (Barr $1989,11)$. If there is clear evidence that the scribes responsible for creating $\mathrm{L}$ paid attention to variation at the lexical level, the latter should form one of the prime levels of investigation.

Thirdly, an index of variation at the lexical level provides new information to researchers that rely on the quantification of the variables for their argumentation. For instance, Geiger $(2013,74)$ argues, "in the nonbiblical scrolls, there are almost 1000 participles preserved [...] In the following manuscripts more than 50 per cent of the qōt'ēl participles are defective: 4Q372 (defective: 13; plene 6); 4Q381 (defective 12; plene 2); 4Q385a (defective 6; plene 1); 4Q387 (defective 6; plene 0); 4Q408 (defective 3; plene 0)." Hornkohl (2014) describes the spellings of Jerusalem (ירושלים vi ירושלם), the number three (שלוש vs. שלש), and, for instance, the scriptio plena of the qal infinitive construct in frequency tables per document. These quantifications are vulnerable a) to confirmation bias, and b) to a lack of understanding of the expected variability in a given text. ${ }^{28}$ To date, the quantification of spelling variation has to rely on individual observations, even if they need not be at the level of individual lexemes, to describe the orthographic peculiarities of a document. It would be beneficial to perform a systematic, quantitative investigation of document-internal spelling variability that could be used to critically evaluate specific frequency counts. The evidence exegetes and philologists alike present could be very fragmentary and biased. This is not to say that the observations about specific orthographic peculiarities are not valuable, but rather to highlight that they become all the more valuable if they are interpreted against the backdrop of a more developed understanding of the orthographic variability of a document. An index of variation provides a sample that is not manually selected.

Fourthly, Barr $(1989,21)$ claims that a concordance of spelling variation should be classified "not under lexemes but under morphological categories; for instance, all qal

27 What Andersen and Forbes $(1986,153)$ declare as fixed, however, is not necessarily fixed when the Dead Sea Scrolls are part of the corpus (for instance, the spellings of כל אלהים). 
imperfects with $o$ vowel spelt with waw." The disadvantage of a model that starts from abstract spelling types, however, is it already relies on an interpretative step that could hide specific tendencies at the lexical level. Higher abstractions, along the lines of the types introduced by Andersen and Forbes and Barr, also hide important information about lexical items that are consistent whilst the higher abstraction is not. The present approach uses almost no theory about the factors that cause the variation, it merely quantifies the variation. This is a purposeful choice as there is no a priori guarantee that abstractions exhibit the same linguistic preferences. A word form could also at some point become part of a scribe's long-term memory and his writing habits.

Finally, the current approach to the study of linguistic variation complements the existing ways of extracting spelling variation in the following ways: a) rather than starting from potential variation (cases where a vowel letter could potentially be used) it starts from the actual, attested variation in the documents; b) rather than starting from a manual, expert-driven pre-selection of spelling types, it uses an inductive selection of features which was not compiled for the study of variation; c) it is not directly dependent on the vocalisation in the Hebrew Bible nor the Tiberian pronunciation; hence, it can be scaled easily and it can be applied to the Scrolls; and d) the variation that is captured is not binary, it is possible that a variable has three or more variants spellings. The extraction of these linguistic profiles provides a natural selection of all the variation one could find in a book. It should be concluded that the advantages of the presented approach are substantial.

\section{Challenges}

Despite the advantages of the study of variation at the lexical level there are also a number of caveats that should be made explicit. Firstly, for this method, linguistic variation is by definition restricted to profiles that occur at least twice within a single document. Regardless of the thousands of variables that can be extracted, this type of index is never exhaustively representative of the variation attested within the corpus. A variation matrix will always capture a sample of the overall variation; this sample is a solid, representative starting point, but it is never exhaustive. The selection procedure is therefore a fine line between gathering sufficient data for the matrix to be informative and representative and being as precise as possible in the data one collects. It is, of course, always possible to find a counterexample, a case of variation which is not captured by the feature extraction and the feature selection, but that is true of any method. The sample of variation is likely to be representative, but there are no formal guarantees of the percentage of actual variation the method covers. This index is a heuristic tool. The assumption is that frequently used words within a document (both function words and content words) constitute primary candidates to quantify linguistic variation. 
Secondly, the quality of the data is difficult to monitor. For his analysis, Barr $(1989,16)$ notes the complexity of data integrity for the analysis of spelling. He mentions "misprints in the standard texts, omissions from printed concordances, overlooking of relevant examples, and errors in typing and proof-reading." The errors are not of such an order of magnitude that they impede the quantification and analysis of the data. ${ }^{29}$ Nonetheless, in the data and notably in the morphological parsing there are mistakes, yet the data are accepted "as is" for the purpose of this article. For future studies, a collaborative version of the index is needed in order to increase the reproducibility of the methods. ${ }^{30}$ This is especially important as the morphological datasets provided by Accordance have, to my knowledge, not been evaluated using quality assurance metrics such as precision and recall. The counts presented below might be slightly different from those found in a concordance or in the available software packages. This is due to the very specific feature extraction method used, and due to the above restrictions.

Thirdly, there are a number of factors that affect the quantitative interpretation of matrix in the shape of Table 3: document length and document partitioning. The documents chosen in Table 3 differ from those used in the remainder of this contribution to illustrate the point that the very way in which the varieties or documents are chosen, and if needed are partitioned into smaller documents, affects the counts and hence the results. Andersen and Forbes (1986, 205-13) have highlighted a statistical method to split documents into smaller documents, but within the restraints of the present study, and given the fact that the feature selection used here is distinct from theirs, the modern canonical document divisions are used. Later studies should clarify the effect of selecting different language varieties.

A final challenge is the fact that the method does not automatically distinguish between orthographic and morphological variation, viz. there is no a priori disambiguation of morphological and orthographic variance; this is primarily orthographic variation, but orthographic and morphological variation are not distinguished from each other and hence manual intervention is required at some point. The resulting index could further be post-processed; several successful extensions have been prepared, but they do require more intensive expert decisions.

29 The data in Accordance are regularly updated in collaboration with Accordance's content providers and hence later replications are likely to contain fewer errors in later editions of the same data.

30 The ETCBC database is currently preparing for the inclusion of the scrolls based on data provided by Marty Abegg. 


\section{Conclusion}

This contribution pioneers an automatically extracted and enhanced index of variation in the Hebrew Bible and the documents found in the Judean Desert. The proposed indices and methods provide a novel way of investigating the linguistic variation that is embedded within the ancient texts. Just as the Masoretes paid close attention to linguistic variants at the lexical level, so too one can now navigate the variation based on hypertext links and a representative sample of variation per individual document. These profiles provide unique insights into the orthographic and morphological practices of the authors/scribes. They are likely to spark new research in variational linguistics as well as a more fine-grained understanding of the linguistic particularities of the documents at hand. In that sense, this contribution takes an important step toward the creation of the linguistic profiles (such as spelling profiles) that Barr argued for. In his study of spelling variation, Barr wonders, "What are the actual patterns of usage in the Masoretic text? How are the different options distributed there?" (Barr 1989, 3). It is now possible to automatically obtain a list of profiles that capture a critical sample of a document's internal variation. The method proposed here can also be extended to other manuscripts, such as the Aleppo Codex, as well as any data that have lexemes and morphological parsing. The index and the procedures presented in this contribution are intended to provoke new steps towards the construction of publicly available databases of linguistic variation in the Hebrew Bible and the Dead Sea Scrolls.

\section{References}

Abegg, M. G. Jr. 2010. “The Linguistic Analysis of the Dead Sea Scrolls: More Than (Initially) Meets the Eye." In Rediscovering the Dead Sea Scrolls: An Assessment of Old and New Approaches and Methods, edited by M. L. Grossman, 52-58. Grand Rapids:

W. B. Eerdmans.

Alexander, P. S., and G. Vermes. 1998. Qumran Cave 4: XIX Serekh Ha-Yahad and Two Related Texts. Discoveries in the Judaean Desert 26. Oxford: Clarendon.

Andersen, F. I., and A. D. Forbes. 1986. Spelling in the Hebrew Bible: Dahood Memorial Lecture. Biblica et Orientalia 41. Rome: Biblical Institute Press.

Ariel, C. 2013. “Orthography: Biblical Hebrew.” In Encyclopedia of Hebrew Language and Linguistics, edited by G. Kahn, vol. 2, 940-48. Leiden: Brill.

Baron, A., and P. Rayson. 2008. "VARD 2: A Tool for Dealing with Spelling Variation in Historical Corpora." Proceedings of the Postgraduate Conference in Corpus Linguistics. http://ucrel.lancs.ac.uk/people/paul/publications/BaronRaysonAston2008.pdf (accessed 1 April 2020).

Barr, J. 1989. The Variable Spellings of the Hebrew Bible: The Schweich Lectures of the British Academy 1986. Oxford: Oxford University Press for the British Academy. 
Cross, F. M., and D. N. Freedman. 1952. Early Hebrew Orthography: A Study of the Epigraphic Evidence. American Oriental Society 36 New Haven:

American Oriental Society.

de Joode, J., and D. Speelman. 2020. "The Orthographic Variability of the Hebrew Bible and the Larger Dead Sea Scrolls: A Computational Approach.” Journal for Semitics (forthcoming).

Dershowitz, I., N. Dershowitz, T. Hasid, and A. Ta-Shma. 2014. "Orthography and Biblical Criticism.” Proceedings of Digital Humanities, Lausanne, Switzerland. https://www.cs.tau.ac.il/ nachumd/papers/Orthography.pdf and http://www.cs.tau.ac.il/ amnon/Papers/DDHT.DH14.poster.pdf (accessed 1 April 2020).

Freedman, D. N. 1969. "Orthographic Peculiarities in the Book of Job.” Erlsr 9, 35-44; reprinted in Divine Commitment and Human Obligation: Selected Writings of David Noel Freedman, edited by J. R. Huddleston, vol. 2, 44-60. Grand Rapids: Eerdmans, 1997.

Freedman, D. N., A. D. Forbes, and F. I. Andersen. 1992. Studies in Hebrew and Aramaic Orthography. Edited by W. H. Propp. Biblical and Judaic Studies from the University of California, San Diego 2. Winona Lake: Eisenbrauns.

Geiger, G. 2013. "Plene Writing of the Qōt'ēl Pattern in the Dead Sea Scrolls." In Hebrew in the Second Temple Period, edited by S. E. Fassberg, M. Bar-Asher, and R. A. Clements, 73-81. Studies on the Texts of the Desert of Judah 108. Leiden: Brill. https://doi.org/10.1163/9789004254794_007

Hornkohl, A. 2014. "Characteristically Late Spellings in the Hebrew Bible: With Special Reference to the Plene Spelling of the O-Vowel in the Qal Infinitive Construct." Journal of the American Oriental Society 134 (4), 643-71. https://doi.org/10.7817/jameroriesoci.134.4.643

Kofoed, J. B. 2005. Text and History: Historiography and the Study of the Biblical Text. Winona Lake: Eisenbrauns.

Rahlfs, A. 1916. "Zur Setzung der Lesemütter im Alten Testament”. Nachrichten of the Göttingen Academy, phil.-histor. Klasse, 315-347.

https://archive.org/details/nachrichten1916akaduoft (accessed 1 April 2020).

Seow, C. L. 2011. "Orthography, Textual Criticism, and the Poetry of Job.” Journal of Biblical Literature 130 (1), 63-85. https://doi.org/10.2307/41304188

Tov, E. 2004. Scribal Practices and Approaches Reflected in the Texts Found in the Judean Desert. Studies on the Texts of the Desert of Judah 54. Leiden: Brill. https://doi.org/10.1163/9789047414346 
Ulrich, E., and P. W. Flint, with a contribution by M. G. Abegg. 2010. Qumran Cave 1: II. The Isaiah Scrolls. Part 2: Introductions, Commentary, and Textual Variants. Discoveries in the Judaean Desert 32 (2). Oxford: Oxford University Press.

Weinberg, W. 1985. The History of Hebrew Plene Spelling. Cincinnati: Hebrew Union College.

Zevit, Z. 1980. Matres Lectionis in Ancient Hebrew Epigraphs. Cambridge, MA: American Schools of Oriental Research. 